\title{
Identifikasi Keragaman Genetik Dengan Karakter Morfologi Artocarpus heterophyllus Lamk Nangka Kalimantan Barat, Indonesia
}

\author{
Identification of Genetic Diversity with Morphological Character \\ Artocarpus heterophyllus Lamk West Borneo, Indonesia \\ Nugraha Banu Safitri ${ }^{1 *}$, Wasian $^{1}$, Tantri Palupi ${ }^{1}$ \\ ${ }^{1}$ Program Studi Magister Agroteknologi, Fakultas Pertanian, Universitas Tanjungpura Pontianak \\ Jl. A. Yani, Pontianak, Kalimantan Barat, 78124 Indonesia \\ E-mail: nugrahasp@yahoo.co.id
}

Diterima 19 Februari 2017/ Disetujui 12 Maret 2017

\begin{abstract}
Jackfruit Artocarpus heterophyllus Lamk.is the fruit of that already long been known, but not much research about jackfruit. The West Kalimantan is a province rich in germplasm good plant forests, plantations and agricultural crops. Methode study aims to review determine genetic diversity with morphological characters and to review determine similarity value between accessions of distance diversity of jackfruit in West Kalimantan. The method used is a method of sampling observations using purposive sampling. Morphological identification using quantitative data and qualitative data.with IPGRI altered data passports being numerical data. The identification results of morphological diversity jackfruit on lead group three big hearts of your scale 20 Cluster analysis using SPSS software version 22. Results First grouping Kubu Raya02 and Pontianak01; The second group Sambas01, Singkawang02, Sambas02, Raya05 Kubu, Kubu Raya01 And Singkawang01; The third group consists Pontianak02, Kubu Kubu raya04 and Raya03. The results of the similarity analysis showed that having the highest similarity coefficient value pair Kubu Raya02 with Kubu Raya02 and the lowest coefficient values on pair Pontianak02 with Kubu Raya04. With the identification of the group can design and plan breeding with conventional crossbreeding methods or using genetic engineering. Mapping using cluster analysis gives an important role to improve the properties of the desired plant.
\end{abstract}

Keywords: Artocarpus heterophyllus.Lamk, Diversity, Genetic Identification, Grouping, Jackfruit, Morphology, West Kalimantan.

\section{ABSTRAK}

Nangka Artocarpus heterophyllus Lamk. Merupakan buah yang sudah lama dikenal namun belum banyak penelitian tentang nangka. Kalimantan Barat merupakan provinsi yang kaya plasma nutfah baik tanaman hutan, perkebunan dan tanaman pertanian. Penelitian ini bertujuan untuk mengetahui keragaman genetik dengan karakter morfologi dan untuk mengetahui nilai similaritas jarak antar aksesi keragaman nangka di Kalimantan Barat. Metode yang digunakan adalah metode observasi pengambilan sampel menggunakan purposive sampling. Identifikasi morfologi menggunakan data kuantitatif dan data kualitatif dengan passport data IPGRI diubah menjadi data numerik. Hasil identifikasi keragaman morfologi pada nangka diperoleh tiga kelompok besar dalam skala 20 analisis cluster menggunakan software SPSS versi 22. Hasil pengelompokan pertama Kubu Raya02 dan Pontianak01; kelompok kedua Sambas01,Singkawang02, SambasO2, Kubu Raya05, Kubu Raya01 dan Singkawang01; kelompok ketiga terdiri Pontianak02, Kuburaya04 dan Kubu Raya03. Hasil analisis similaritas menunjukkan bahwa memiliki nilai koefisien similaritas tertinggi pasangan Kubu Raya02 dengan Kubu Raya02 dan nilai koefisien terendah pada pasangan Kubu Raya04 dengan Pontianak02. Dengan identifikasi kelompok dapat merancang dan merencanakan pemuliaan tanaman dengan metode persilangan konfensional maupun menggunakan rekayasa genetika. Pemetaan menggunakan analisis cluster memberikan peran penting untuk memperbaiki sifat-sifat tanaman yang dikehendaki.

Kata kunci: Artocarpus heterophyllus. Lamk, Genetik, Identifikasi, Kalimantan Barat, Keragaman, Morfologi, Nangka, Pengelompokan.

\section{PENDAHULUAN}

Nangka Artocarpus heterophyllus Lamk. merupakanbuah yang sudah lama dikenal namun belum banyak penelitian tentang nangka. Identifikasi keragaman genetik merupakan lagkah awal untuk mengetahui informasi genetik tanaman nangka. Seleksi keunggulan varietas serta pemuliaan tanaman menggunakan metode persilangan dan 
rekayasa genetika sebelumnya perlu dilakukan identifikasi karakter morfologi.

Nangka merupakan bagian dari sumber daya alam berupa kekayaan plasma nutfah Kalimantan Barat. Penelitian ini mengungkap apakah masih dalam keluarga yang sama ataukah memiliki keragaman sehingga muncul fenotipe yang berbeda-beda. Hal ini menjadi penting ketika akan melestarikan dan memuliakan plasma nutfah sekaligus yang memiliki nilai komersial yang tinggi, setelah mengetahui keragaman genetika ini pemulia tanaman dapat memilih dan menyeleksi untuk mengembangkan sesuai dengan keperluan pemulia.

Penelitian ini dapat memberikan informasi awal pada pemuliaan tanaman dalam menyeleksi tanaman nangka yang berkualitas baik. Dapat memberikan informasi pada pemuliaan tanaman dalam perakitan varietas baru dengan keunggulan tertentu, dapat direkomedasikan menjadi varietas unggul baru.Hasil penelitian Palupi (2011) karakter nangka pada kebun koleksi Universitas Gajah Mada menunjukkan variasi morfologi.Berdasarkan dendrogram dikelompokkan menjadi 2 kelompok yaitu dengan similaritas tertinggi $76.21 \%$ terdapat pada provenan Kalimantan dan Lombok.

Penelitian dengan menguji sampel tanaman nangka yang berada di Kalimantan Barat, identifikasi morfologi langsung dilaksanakan dilapangan. Identifikasi morfologi dapat meghasilkan karakteristik fenotipe sebagai faktor pembeda dari varietas tanaman. Penelitian ini bertujuan untuk mengetahui keragaman genetik tanaman nangka dan tingkat similaritas dengan keragaman morfologi di Kalimantan Barat. Plasmanutfah nangka jika telah diketahui keragamannya, maka penelitian ini ingin mengetahui nilai similaritas jarak antar aksesi keragaman nangka di Kalimantan Barat sehingga pemanfaatan lebih lanjut akanterarah sesuai dengan karakter tanaman.

\section{BAHAN DAN METODE}

Penelitian identifikasi morfologi dilaksanakan di kebun masyarakat yang ada di Kabupaten Sambas, Kota Singkawang, Kabupaten Kubu Raya dan Kota Pontianak. Penelitian dilaksanakan \pm 11 bulan sejak bulan Januari November 2015.

\section{Pengamatan Karakterisasi Morfologi}

Metode yang digunakan adalah metode observasi pengambilan sampel menggunakan Purposive sampling. Sampel Purposive adalah teknik penentuan sampel dengan pertimbangan tertentu. Sampel ini digunakan untuk penelitian kualitatif (Sugiyono, 2013). Penelitian Identifikasi Karakter morfologi termasuk pada penilaian kualitatif dengan persyaratan teknis dan pertimbangan peneliti. Diyakini bahwa tanaman bukan berasal dari perbanyakan vegetatif, pertanaman berasal dari seedling (tumbuh dari biji). Karena pengamatan dengan persyaratan tertentu aksesi atau sampel yang diamati tidak secara acak namun terpilih danberdasarkan pertimbangan yang dapat memenuhi kriteria dari tujuan penelitian, dengan persyaratan tertentu tanpa rancangan percobaan.

Pengamatan morfologi dimulai dengan melakukan eksplorasi ke beberapa kabupaten di Kalimantan Barat.Pengamatan karakter kualitatif menggunakan perangkat Passport Data, berdasarkan IPGRI (International Plant Genetic Resources Institute) (2000).Pengukuran kualitatif, kuantitatif dengan menggunakan sekala 1-9 dan karakteristik yang diamati sesuai dengan IPGRI. Parameter yang diamati pada seperti pada Tabel 1 .

Setelah diperoleh data dikompilasi dalam data base untuk dilanjutkan olah data, baik data kualitatif maupun kuantitatif di ubah menjadi numerik terlebih dahulu sehingga tersusun menjadi kode biner. Kemudian dari pengkodean biner disimpan dalam Microsoft Office Exel dianalisis menggunakan program SPSS 22, selanjutnya dianalisis similiaritas menggunakan metode hierarchical. Metode hierarchical ini dapat mengelompokkan satu atau lebih aksesi yang mempunyai kesamaan paling dekat.

\section{Pelaratan Pengukuran}

Altimeter SUNTO, Klinometer SUNTO, GPS(Global Positioning System), GARMIN 60 csx , Kaliper, Refractometer ATAGO, pH meter, Penggaris, Rol Meter, Timbangan

\section{Analisis Data}

Analisis data pengamatan lapangan menggunakan program SPSS 16 Aryanti, I et.al (2015).

a. Analisis Similarity(Kekerabatan) pada hasil Identifikasi karakter morfologi. Koefisien antar karakter morfologi diolah menggunakan prosedur Agglomeration schedule dan Proximity matrix pada SPSS 22

b. Analisis Komponen Utama

Analisis komponen utama adalah analisis dilakukan pada pada hasil identifikasi karakter morfologi dalam bentuk data similarity (jarak kedekatan antar aksesi). Hasil analisis similarity dibandingkan pola dendrogram pada karakter morfologi dan karakter molekuler

c. Analisis Pengelompokan

Analisis gerombol (clustering) seluruh data, baik data fenotipik, RAPD maupun data gabungan masingmasing dianalisis menggunakan Sequential, Agglomerative, Hierarchical, and Furthest neighbor ( Euclidiean distance) pada program SPSS versi 22. Hasil analisis disajikan dalam bentuk dendogram dan proximity matrix

d. Analisis Korelasi Antara Karakter Kuantitatif dan Ploidi

Analisis korelasi untuk melihat tingkat kecenderungan terpaut antara karakter kuantitatif, dan jenis ploidi dilakukan dengan menggabungkan data kuantitatif dan data skor jenis ploidi masing-masing aksesi. Analisis dilakukan berdasarkan prosedur analisis similaritas dalam SPSS 22. 
Tabel 1.Parameter Pengamatan Karakter Kuantatif Tanaman dan Buah Nangka Kalimantan Barat

\begin{tabular}{|c|c|}
\hline (n) & No Variabel \\
\hline 1. Umur Tanaman & 20. Tebal kulit \\
\hline 2. Tinggi tanaman & 21. Panjang biji $(\mathrm{cm})$ \\
\hline 3. Tinggi Cabang Pertama & 22. Lebar Biji $(\mathrm{cm})$ \\
\hline 4. Diameter batang & 23. Jumlah biji per kg \\
\hline 5. Diameter Tajuk (kanopi) & 24. Berat 100 biji \\
\hline 6. Kerapatan Percabangan & 25. Ketebalan kulit biji \\
\hline 7. Dominansi Apikal & 26. Ratio biji/daging buah \\
\hline 8. Panjang Helai & 27. Jumlah Bulb (daging buah) $/ \mathrm{kg}$ \\
\hline 9. Lebar Helai daun & 28. Berat serpihan per kg buah \\
\hline 10. Panjang Tangkai daun & 29. Berat daging buah dan biji \\
\hline 11. Waktu berbuah setelah tanam (Y) & 30. Rasio buah/ serpihan \\
\hline 12. Waktu berbunga sampai buah masak (D) & 31. Panjang daging buah $(\mathrm{cm})$ \\
\hline 13. Kabiasaan kelompok buah (tipe) & 32. Lebar daging buah $(\mathrm{cm})$ \\
\hline 14. Panjang tangkai Buah $(\mathrm{cm})$ & 33. Tebal daging buah \\
\hline 15. Diameter tangkai buah $(\mathrm{cm})$ & 34. Bentuk daging buah \\
\hline 16. Panjang buah $(\mathrm{cm})$ & 35. Panjang tulang $(\mathrm{cm})$ \\
\hline 17. Lebar buah $(\mathrm{cm})$ & 36. Diamater tulang $(\mathrm{cm})$ \\
\hline 18. Berat buah $(\mathrm{kg})$ & 37. Vivipar $(0 / 1)$ \\
\hline 19. Berat kulit (kg) & \\
\hline
\end{tabular}

Tabel 2.Parameter Pengamatan Karakter Kualitatif Tanaman dan Buah Nangka Kalimantan Barat

\begin{tabular}{ll}
\hline No Variabel & No Variabel \\
\hline 1. Keadaan tajuk & 19. Bentuk tulang \\
2. Tekstur kulit batang & 20. Kepadatan tulang \\
3. Bentuk batang & 21. Latek exudate \\
4. Bentuk Tajuk & 22. Kualitas buah \\
5. Tipe Pertumbuhan & 23. Kemolekan buah \\
6. Tipe Percabangan & 24. Lama penyimpanan \\
7. Bentuk Ujung daun & 25. Warna kulit buah \\
8. Bentuk Pangkal daun & 26. Permukaan buah \\
9. Bentuk daun & 27. Permukaan biji \\
10. Warna daun & 28. Pola permukaan biji \\
11. Permukaan atas daun & 29. Warna kulit biji \\
12. Permukaan Bawah daun & 30. Kandungan serat daging buah \\
13. Pelepah daun & 31. Teksture daging buah \\
14. Bentuk tangkai daun & 32. Rasa daging buah \\
15. Alur tangkai daun & 33. Aroma daging buah \\
16. Seludang tangkai daun & 34. Daging buah berair/tidak \\
17. Warna kulit buah & sangat \\
18. Permukaan buah & Warna daging buah \\
\hline
\end{tabular}

\section{HASIL DAN PEMBAHASAN}

Identifikasi karakter morfologi dilaksanakan berdasarkan rancangan purposive sampling. Hasil pengambilan sampel yang diperoleh dari 4 Kabupaten / Kota yaitu Sambas, Kubu Raya, Singkawang dan Pontianak sebagai aksesi. Telah dilakukan identifikasi karakter morfologi terhadap 11 aksesi tanaman Nangka dengan karakter morfologi yang dapat dibedakan dalam koloni sehingga memenuhi syarat sebagai aksesi. Hasil analisis identifikasi karakter morfologi dan molekuler sebagai berikut :

\section{a. Hasil}

Hasil identifikasi karakter morfologi dari rencana 92 karakter dengan jumlah 304 subkarakter hanya 76 
karakter dengan jumlah 284 subkarakter yang dapat terpenuhi karena pada karakter bunga tidak tersedia di lapangan.

Kode lapangan menunjukkan asal aksesi yang diidentifikasi kemudian kode lapangan diterjemahkan menjadi nama aksesi adalah sebagai berikut kode SSST01 menjadi SAMBAS01, kode SSST02 menjadi SAMBAS02, kode KSCST01 menjadi SINGKAWANG01, kode KSCST02 menjadi SINGKAWANG02, kode KPESSB01 menjadi PONTIANAK01, KPDSWSB01 menjadi PONTIANAK02, kode KKRBRRJ01 menjadi KUBURAYA01, kode KKRBRRJ02 menjadi KUBURAYA02, kode KKRBRRJ03 menjadi KUBURAYA03, kode KKRBSRJ01 menjadi KUBURAYA04 dan kode KKRKJRJ01 menjadi KUBURAYA05.

Data hasil passport kemudian di lanjutkan pengkodean binner menggunakan Microsoft Excel 2007 disusun lengkap setiap aksesi dengan subkarakter , yang terpenuhi nilai 1 dan tidak terpenuhi nilai 0 .

Selanjutnya identifikasi karakter morfologi di analisis kelompok menggunakan metode hierarchical dan Proximity matrix terbentuk jarak antar dua indikator untuk keseluruhan variabel yang digunakan, kemudian dianalisis cluster sehingga berkelompok sesuai kemiripan masing-masing menggunakan perangkat lunak SPSS 22.

Diperoleh dendrogram similaritas seperti pada gambar 1 sebagai berikut :

\section{b. Pembahasan}

Berdasarkan analasis cluster (analisis kelompok) identifikasi keragaman nangka Kalimantan Barat menggunakan program SPSS 22 diperoleh dendrogram clusterterdiri 3 kelompok besar yaitu kelompok KUBURAYA02 dan PONTIANAK01 Kelompok kedua terdiri dari SAMBAS01, SINGKAWANG02, SAMBAS02, KUBURAYA05, KUBURAYA01 dan SINGKAWANG01. Kemudian kelompok ketiga terdiri dari PONTIANAK02, KUBURAYA04 dan KUBURAYA03.Sedangkan menurut penelitian Adelina et.al (2006) identifikasi morfologi dan iso ensim menggunakan analisis kelompok diperoleh 6 kelompok nangka di wilayah kabupaten Donggala, Sulawesi Tengah.

Karakter pembeda pada kelompok pertama dengan sub karakter khusus warna kulit buah hijau, kuning, kuning kehijauan. Karakter bentuk buah tidak beraturan (irregular) dan Oval bengkok, sehingga keduanya ini sangat berbeda dengan aksesi yang lain berdasarkan diagram dendrogram.

Berdasarkan analisis similaritas jarak yang dekat menunjukkan bahwa banyaknya karakter atau sub karakter morfologi yang sama antara sampel PONTIANAK02 dengan KUBURAYA04. Sebaliknya jika nilai koefisien tertinggi maka karakter morfologi yang diidentifikasi tidak mirip antar keduanya.

Hasil analisis dendrogram dan analisis koefisien menggambarkan bahwa tanaman nangka di Kalimantan Barat melalui identifikasi karakter morfologi memiliki keragaman genetik yang sangat beragam. Dalam penelitian Khan et.al (2010)menyebutkan bahwa keragaman bedasarkan pengamatan morfologi pada karakter kualitatif dan kuantitatif lebih baik nangka budidaya dibanding nangka tumbuh alami di hutan. Perbedaan antar populasi dikarenakan bebas dan semi bebas dengan pengaruh seleksi manusia.

Dendrogram Similaritas Nangka Kalimantan Barat

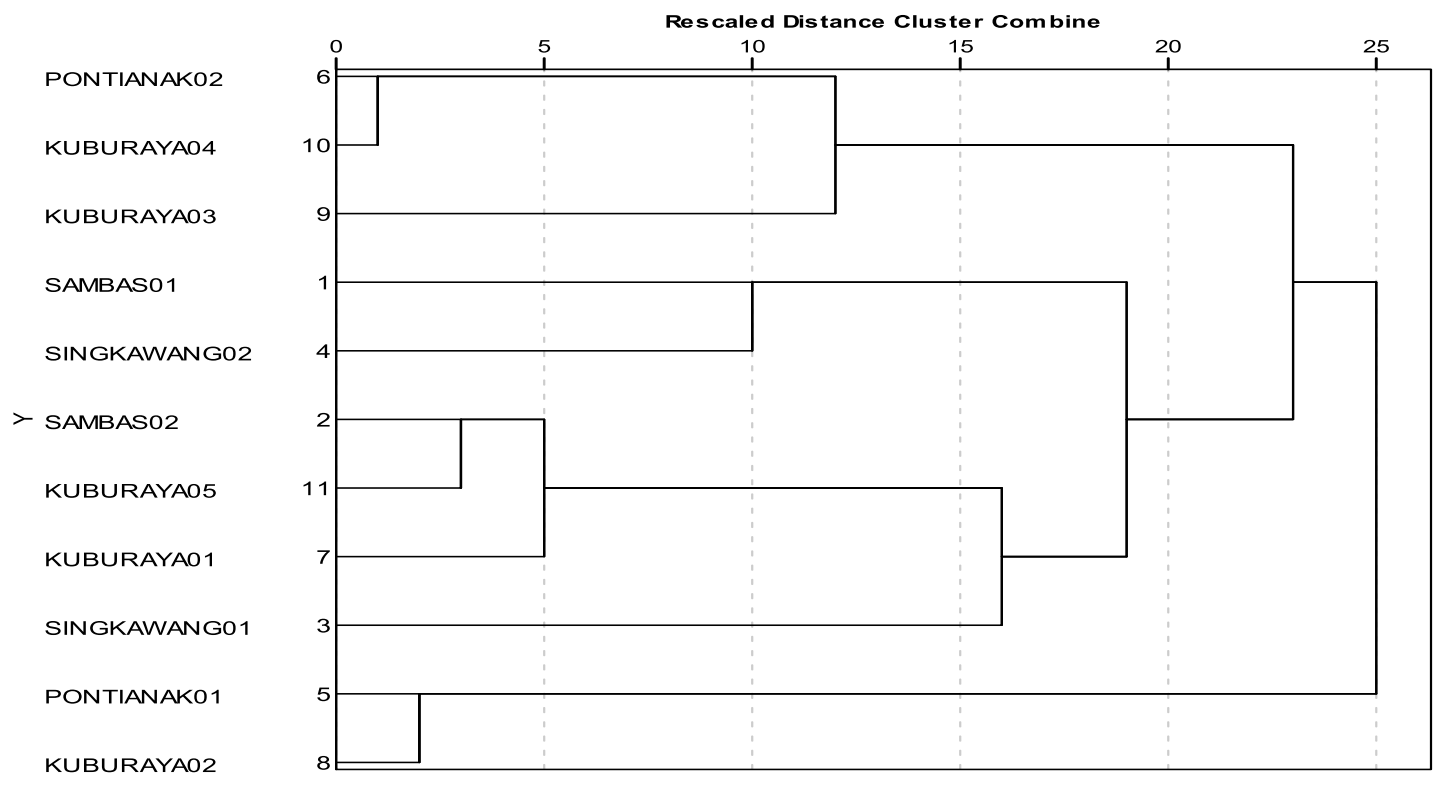


Gambar 1. Dendrogram Similaritas Nangka Kalimantan Barat

Tabel 3. Analisis Koefisien Similaritas Morfologi Nangka Kalimantan Barat

\begin{tabular}{|c|c|c|c|c|c|c|c|c|c|c|c|}
\hline \multirow[b]{2}{*}{ SAMPEL } & \multicolumn{11}{|c|}{ KOEFISIEN } \\
\hline & $\begin{array}{l}\bar{\sigma} \\
0 \\
\sum \\
\sum_{i=}^{\infty}\end{array}$ & 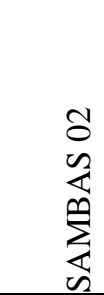 & $\begin{array}{l}0 \\
0 \\
z \\
z \\
z \\
0 \\
0 \\
z \\
\vdots \\
0\end{array}$ & 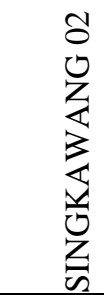 & 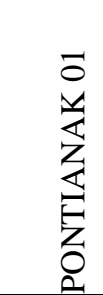 & 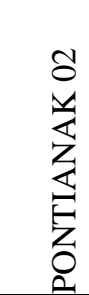 & 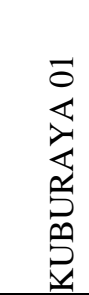 & 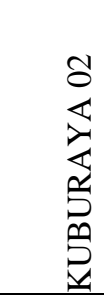 & 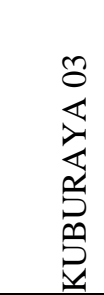 & 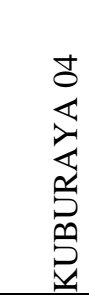 & 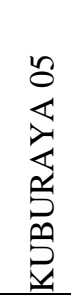 \\
\hline SAMBAS 01 & 0 & - & - & - & - & - & - & - & - & - & - \\
\hline SAMBAS 02 & 8.77 & 0 & & - & - & - & - & - & - & - & - \\
\hline SINGKAWANG 01 & 9.64 & 9.055 & 0 & - & - & - & - & - & - & - & - \\
\hline SINGKAWANG 02 & 9.05 & 8.660 & 9.84 & 0 & - & - & - & - & - & - & - \\
\hline PONTIANAK 01 & 9.38 & 8.544 & 9.43 & 9.165 & 0 & - & - & - & - & - & - \\
\hline PONTIANAK 02 & 8.77 & 8.367 & 8.83 & 10.14 & 8.660 & 0 & - & - & - & - & - \\
\hline KUBURAYA 01 & 9.38 & 8.660 & 9.53 & 9.274 & 9.798 & 8.54 & 0 & - & - & - & - \\
\hline KUBURAYA 02 & 9.79 & 9.539 & 10.0 & 10.29 & 8.367 & 9.74 & 9.89 & 0 & - & - & - \\
\hline KUBURAYA 03 & 9.48 & 10.14 & 9.84 & 10.19 & 8.944 & 9.00 & 9.59 & 10.39 & 0 & - & - \\
\hline KUBURAYA 04 & 9.11 & 8.832 & 9.27 & 9.110 & 8.307 & 8.24 & 8.66 & 10.05 & 9.220 & 0 & - \\
\hline KUBURAYA 05 & 8.94 & 8.426 & 9.11 & 9.695 & 8.485 & 8.88 & 8.48 & 9.381 & 8.944 & 9.53 & 0 \\
\hline
\end{tabular}

Keterangan: Nilai koefisien tertinggi adalah 10.392 jarak antara KUBURAYA02 dan KUBURAYA03, nilai koefisien terendah 8.246 jarak antara KUBURAYA04 dan PONTIANAK02

Varietas yang beragam dapat dibedakan karakter morfologinya dalam populasi spesies tanaman nangka. Tertuang dalam dalam UU no 29 tahun 2000 tentang perlindungan varietas bahwa merupakan varietas baru sekurang-kurangnya satu karakter (sifat) yang menentukan dan apabila diperbanyak tidak mengalami perubahan, ditandai oleh bentuk tanaman, pertumbuhan tanaman, daun, bunga, biji, buah dan ekspresi karakteristik genotype atau kombinasi genotype.

Diagram dendrogram hasil analisis kelompok dapat di telusuri beberapa pembeda karakteristik morfologi berdasarkan passport data tanaman nangka Kalimantan Barat.Diketahui bahwa karakter morfologi pada setiap aksesi menunjukkan karakter yang berbeda karakter bentuk tajuk, bentuk daun, bentuk buah, warna kulit buah, bentuk ujung daun, bentuk nyamplung, tekstur daging buah, warna daging buah dan bentuk biji.

Masing-masing aksesi tidak terdapat karakter yang sama persis dalam deretan sub karakter pada identifikasi karakter morfologi, ini menunjukkan bahwa nangka Kalimantan Barat memiliki keragaman yang tinggi. Hal ini dikarenakan sifat tanaman nangka sebagai tanaman monoecious sebagai tanaman penyerbuk silang. Menurut Jagadesh et al, (2007) nangka memiliki keragaman akibat menyerbuk silang dan perbanyakan melalui biji.

Tanaman nangka hasil analisis dendrogram pengelompokkan berdasarkan tingkat kemiripan terbagi menjadi 3 kelompok karakter pada masing masing kelompok sebagai berikut : 
Tabel.4 Karakteristik Tanaman Nangka Kalimantan Barat, Indonesia

\begin{tabular}{|c|c|c|c|}
\hline Karakteristik & Kelompok 1 & Kelompok 2 & Kelompok 3 \\
\hline Golongan varietas & Bersari bebas & Bersari bebas & Bersari bebas \\
\hline Tinggi Tanaman & $5.1-9.6 \mathrm{~m}$ & $4.85-9.6 \mathrm{~m}$ & $7.2-9.6 \mathrm{~cm}$ \\
\hline Bentuk tajuk tanaman & Piramida & Piramida lebar & teratur \\
\hline Bentuk penampang batang & Tegak & Semi-tegak & Semi tegak \\
\hline Diameter batang & $11.3-12.561 \mathrm{~cm}$ & $7.3-20.67 \mathrm{~cm}$ & $12.72-25.122 \mathrm{~cm}$ \\
\hline Warna batang & Hijau & Hijau & Hijau \\
\hline Bentuk daun & Elliptic & Oblong - elips & Hampir ellips \\
\hline \multirow[t]{2}{*}{ Ukuran daun } & $P: 16.06-17.57 \mathrm{~cm}$ & P: $9.82-17.54 \mathrm{~cm}$ & $P: 14.35-17.61 \mathrm{~cm}$ \\
\hline & $\mathrm{L}: 9.05-9.49 \mathrm{~cm}$ & $\mathrm{~L}: 4.42-10.6 \mathrm{~cm}$ & $\mathrm{~L}: 6.79-8.24 \mathrm{~cm}$ \\
\hline Warna daun & Hijau tua & Hijau tua & Hijau tua \\
\hline Bentuk buah & Ellips & Obloid - bulat & Ellips \\
\hline \multirow[t]{2}{*}{ Ukuran buah } & $\mathrm{P}: 45-49 \mathrm{~cm}$ & P: $24-47 \mathrm{~cm}$ & $P: 36.4-70 \mathrm{~cm}$ \\
\hline & $\mathrm{D}: 24-25 \mathrm{~cm}$ & $\mathrm{D}: 22-29 \mathrm{~cm}$ & D: $22-32.5 \mathrm{~cm}$ \\
\hline Warna kulit buah & Hijau & $\begin{array}{c}\text { Hijau kekuningan - } \\
\text { kuning }\end{array}$ & Kuning \\
\hline Duri buah & Berduri & berduri & Berduri \\
\hline Ketebalan daging buah & $0.5-1 \mathrm{~cm}$ & $0.5-2.8 \mathrm{~cm}$ & $1.4-2.3 \mathrm{~cm}$ \\
\hline Warna daging buah & kuning & Kuning & Kuning tua \\
\hline Rasa daging buah & Kurang manis & Manis & Manis \\
\hline Aroma buah & lembut & menyengat & lembut \\
\hline Bentuk biji & ellipsoid & irregular & ellips \\
\hline Warna biji & Kuning muda & Putih - cream & kuning \\
\hline Kandungan air & berair & Tidak berair & Juicy \\
\hline Kadar gula & $16.3-19.8^{\circ} \mathrm{Brix}$ & $17.5-36.3^{\circ}$ Brix & 21.3-48.2 ${ }^{\circ} \mathrm{Brix}$ \\
\hline Berat per buah & $14.9-14.95 \mathrm{Kg}$ & $5.5-15.45 \mathrm{~kg}$ & $8.85-38.35 \mathrm{Kg}$ \\
\hline Perkiraan umur pohon induk tunggal & 10- 20 tahun & 5-40 tahun & $10-25$ th \\
\hline
\end{tabular}

Berdasarkan analisis cluster nangka Kalimantan Barat di kelompokkan menjadi tiga kelompok, Karakteristik yang menyolok pada pengelompokan ini adalah bentuk buah yang berkorelasi dengan ukuran buah. Kelompok pertama berbentuk ellips berukuran antara 14.9-14.95 Kg sedangkan kelompok kedua berbetuk bulat dengan berat buah antara 5.5 $15.45 \mathrm{~kg}$ dan berbeda dengan kelompok tiga dengan bentuk buah ellips dengan berat buah $8.85-38.35 \mathrm{~kg}$. Kelompok satu dan kelompok tiga dari bentuk sama sama elips tetapi nampak perbedaan pengelompokannya dari warna daging buah kelompok tiga berwarna kuning tua.

Menurut Sullasih et.al (2013) keragaman nangka di wilayah Bogor cukup tinggi dengan rentang koefisien kemiripan 23-100\%, hal ini dikuatkan dengan perbedaan bentuk buah yang sangat mencolok pada nangka Bola berbentuk bulat dan yang lainnya berbentuk elips.Buah ukuran kecil yang termasuk kelompok 2 cenderung memiliki aroma yang lebih kuat dengan bentuk biji irregular cenderung tidak ellips tetapi agak gemuk. Karakter umum terdapat pada kelompok 3 rasa buah lebih juicy dibanding dengan kelompok yang lain hasil ini secara visual lebih menarik karena tidak terlalu basah dan tidak juga kering sehinga berpengaruh juga pada tingkat kemanisan yang tidak terlalu manis. Berbeda dengan kelompok 2 cenderung lebih kering tebal dan manis sehingga lengket tekstur cenderung seperti berserat.

Identifikasi kelompoksangat membantu dalam merancang dan merencanakan pemuliaan tanaman dengan metode persilangan konfensional maupun menggunakan rekayasa genetika. Pemetaan menggunkan analisis cluster memberikan peran penting untuk memperbaiki sifat-sifat tanaman yang dikehendaki.Menurut Fatimah.S(2011) dua kelompok memiliki koefisien rendah pada karakter bunga, umur berbunga dan tinggi tanaman pada tanaman jagung maka akan memberikan peluang untuk dilakukan perbaikan tanaman. 

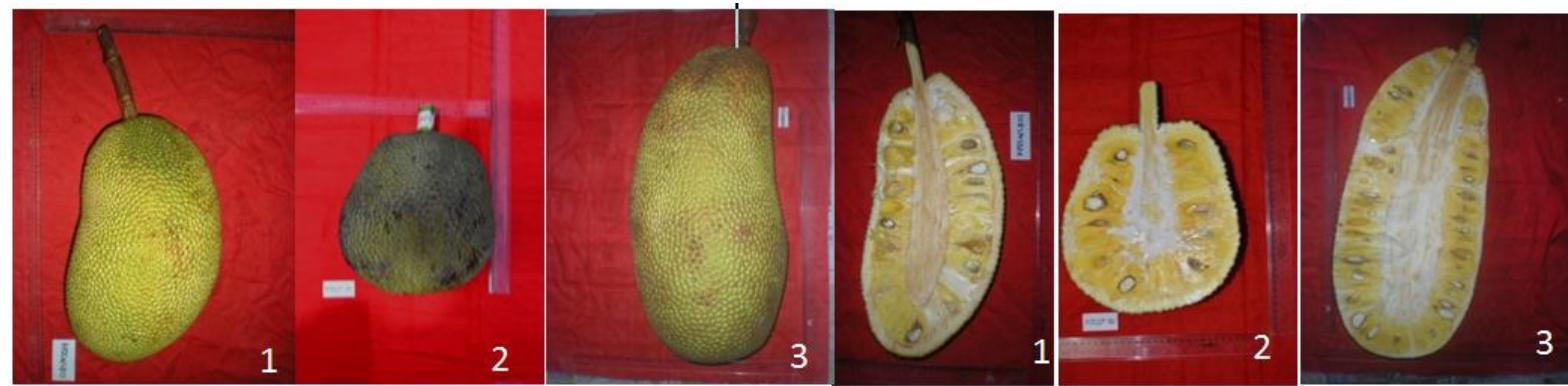

Gambar 2 : Karakter buah nangka pada tiga kelompok

Keterangan : karakter buah, daging buah, bentuk buah dan warna buah

\section{KESIMPULAN}

1. Terdapat keragaman genetik nangka Kalimantan Barat berasarkan identifikasi morfologi dengan analisis kelompok terbagi menjadi 3 kelompok besar Pada Skala 20, yaitu kelompok KUBURAYA02 dan PONTIANAK01 Kelompok kedua terdiri dari SAMBAS01, SINGKAWANG02, SAMBAS02, KUBURAYA05, KUBURAYA01 dan SINGKAWANG01. Kemudian kelompok ketiga terdiri dari PONTIANAK02, KUBURAYA04 dan KUBURAYA03. Terdapat keragaman genetik nangka Kalimantan Barat berdasarkan marka molekuler

2. Dapat diketahui tingkat similaritas antar aksesi identifikasi morfologi dalam diagram dendrogram, pada titik terjauh nilai koefisien 10.392 yaitu KUBURAYA02 dengan KUBURAYA03, sedangkan terdekat dengan nilai koefisien 8.246 yaitu antara PONTIANAK02 dan KUBURAYA04.

3. Keragaman genetik dengan koefisien keragaman yang besar akan memberikan peran penting dalam perbaikan sifat-sifat tanaman melalui pemuliaan tanaman.

4. Diagram dendrogram dapat menjadi dasar pertimbangan memilih sifat tanaman yang dikehendaki dalam memperbaiki sifat-sifat tanaman melalui kegiatan pemuliaan tanaman baik persilangan konfensional maupun rekaya genetika.

\section{DAFTAR PUSTAKA}

Adelina E., Tambing Y., Budiarti T., dan Murniati E. 2006. Identifikasi Keragaman Kultivar Nangka Berdasar Ciri Morfologi dan Analsis isoenzim. Jurnal Agrisains 7(3):150-155 ISSN: 1412-3657

Aryanti,I. Bayu, S.E, Kardhinata , H.E. 2015.Identifikasi Karakteristik Morfologis dan Hubungan Kekerabatan pada Tanaman Jahe (Zingiber officinale Rosc.) di Desa Dolok Saribu Kabupaten Simalungun.Program Studi Agroekoteknologi, Fakultas Pertanian USU, Medan.

Asy'ari M. dan Noer, S. A. 2005.Optimasi Konsentrasi $\mathrm{MgCl}_{2}$ dan Suhu Annealing Pada Proses Amplifikasi Mulltifragmens mtDNA Dengan Metode PCR. FMIPA
Bardakci F. 2001. Random Amplified Polymorphic DNA (RAPD) Marker, Cumhuriyet University.Faculty Arts and Science.Departement of Biology. 58140. SivasTurkey

Fatimah,.S.2011. Analisa Vaiasi Genetik Tanaman Jagung (Zea mays.L) Hasil Persilangan Kultivar Tambin dan Srikandi Kuning, Jurnal Agrovigor Vol.4 No. 2 ISSN:1979 5777

IPGRI. 2000. Descriptors for Jackfruit (Artocarpus heterophyllus). International Plant Genetic Resources Institute. Rome. Italy. ISBN:92-9043-450-3

Jangadeesh, SL, Reddy BS, Basavaraj N, Swamy GSK, Gorbal K Hedge L, Raghavan GSV, Kajjidoni ST. 2007. Inter Tree Variability for Fruit Quality in Jackfruit Selections of Western GAht of India. Scientie Horticulturae 112: 382-387

Khan R. Zerega N. Hossain. S. Zuberi MI. 2010. Jackfruit (Artocarpus heterophyllus Lamk.)Diversity in Bangladesh: Land Use and Artificial Selection. Economic Botany 64 (2):124-136

Krisnan G.A, Sabu.S.T, Sible, G.V dan Xavier L. 2015.Genetic Diversity Analisis in Jackfruit Selection of Kuttanad Region Using RAPD Technique. Regional Agriculture Reseach Station, Kerala Agricultural University, Kumarakom, Kottayam, Kerala

Gopalsamy,J.,Anburaj. J., Sundaravadivelan, C., Kuberan,T. Kumar, P., Starlin T., dan Mariselvan M. 2012.Molecular Marker (Rapd) Based Fingerprinting on Jackfruit to Estimate The Genetic Diversity, International Journal of Aplied Bioresearch IJAB. Sivakasi, India.

Palupi D. 2011.Keragaman Genetik Tanaman Nangka (Artocarpus heterophyllus) di Indonesia Berdasarkan Karakter Morfologis dan Molekular. Tesis Universitas Gadjah Mada. Yogyakarta.

Sugiyono.2012. Metode Penelitian Administrasi.Alfabet. Jakarta

Sulassih, Sobir, Santoso E. 2013. Studi Keragaman Genetik Nangka (Artocarpus heteropillus Lamk) Berdasarkan marka Morfologi. SABRAO Journal of Breeding and Genetics. 
